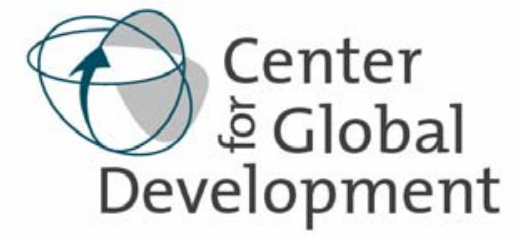

\section{Working Paper Number 51} December 2004
Food Security and Economic Growth: An Asian

Perspective

by C. Peter Timmer

\begin{abstract}
Food security is an elusive concept. Many economists doubt that it has any precise meaning at all. Having enough to eat on a regular basis, however, is a powerful human need, and satisfying this need drives household behavior in both private and public markets in predictable ways. Indeed, the historical record suggests that policy initiatives by central governments to satisfy this need for food security-at the level of both households and national markets-can speed economic growth in countries where a substantial proportion of the population does not get enough to eat.

Paradoxically, in most successfully developing countries, especially those in the rice-based economies of Asia, the public provision of food security quickly slips from its essential role as an economic stimulus into a political response to the pressures of rapid structural transformation, thereby becoming a drag on economic efficiency. The long-run relationship between food security and economic growth thus tends to switch from positive to negative over the course of development. Because of inevitable inertia in the design and implementation of public policy, this switch presents a serious challenge to the design of an appropriate food policy.
\end{abstract}




\title{
FOOD SECURITY AND ECONOMIC GROWTH: AN ASIAN PERSPECTIVE
}

\author{
By C. Peter Timmer* \\ Center for Global Development \\ November 22, 2004
}

Food security and economic growth interact with each other in a mutually reinforcing process over the course of development. It is only in modern times that entire societies have achieved food security. ${ }^{1}$ Earlier, only privileged members of society were able to escape from chronic hunger and the constant threat of famine (Fogel, 1991). Many countries in the developing world, especially in Africa and South Asia, have not managed this escape. In these countries, understanding the factors that cause widespread hunger and vulnerability to famines, and the mechanisms available to alleviate their impact, remain important intellectual challenges (Ravallion, 1987, 1997; Sen, 1981; Dreze and Sen, 1989).

There is a different way to pose the question, however. Rather than asking how to cope with hunger and famine, the question might be how to escape from their threat altogether. As Fogel (1991) has emphasized, this is a modern question which is only partly answered by the institutional and technological innovations that are at the heart of modern economic growth (Kuznets, 1966). Without these innovations, the modern escape from hunger to food security would not have been possible. But the record of economic growth for the developing countries since the 1950s shows that even in countries with relatively low levels of per capita income, government interventions to enhance food security can lift the threat of hunger and famine. The countries most successful at this task are in East and Southeast Asia, although the experience in South Asia has been instructive as well (Timmer, 2000).

\footnotetext{
* Peter Timmer is a Senior Research Fellow at the Center for Global Development. This paper was delivered as the H.W. Arndt Memorial Lecture at Australian National University, Canberra, on November 22, 2004. I am indebted to my family and many colleagues for extended discussions over the past three decades on these topics, but hold none of them responsible for the arguments here. A revised version of the paper will appear in the May (2005) issue of Asia-Pacific Economic Literature (Canberra).

${ }^{1}$ Defining food security is an exercise in itself, especially when both macro and micro dimensions are included in the definition. In an influential review, Simon Maxwell (1996) listed 32 (!) different definitions of the term used by various authors between 1975 and 1991. Each definition is sensible in some context. The goal of this essay is to understand the causal mechanisms that establish two-way links between economic growth and food security. Almost any definition that is intuitively plausible will do for that purpose.
} 


\section{Food Security: Conceptualizing the Issues}

That rich countries have little to fear from hunger is a simple consequence of Engel's Law; consumers have a substantial buffer of nonfood expenditures to rely on, even if food prices rise sharply. In a market economy, the rich do not starve. Wars, riots, hurricanes, and floods, for example, can disrupt the smooth functioning of markets, and all in their wake can perish. But rich societies usually have the means to prevent or alleviate such catastrophes, social or natural. Food security in rich societies is simply part of a broader net of social securities.

\section{Food Security and Public Action}

Without the buffer of Engel's Law, consumers in poor countries are exposed to continued hunger and vulnerability to shocks that set off famines (Anderson and Roumasset, 1996). And yet, several poor countries have taken public action to improve their food security. The typical approach reduces the numbers of the population facing daily hunger by raising the incomes of the poor, while simultaneously managing the food economy in ways that minimize the shocks that might trigger a famine. These countries, some of them quite poor, have managed the same "escape from hunger" that Fogel documents for Europe during the $19^{\text {th }}$ and early $20^{\text {th }}$ centuries.

This essay has a main premise: an early escape from hunger-achieving food security at the societal level-is not just the result of one-way causation from economic growth generated by private decisions in response to market forces. Improved food security stems directly from a set of government policies that integrates the food economy into a development strategy that seeks rapid economic growth with improved income distribution (Timmer, Falcon, and Pearson, 1983). With such policies, economic growth and food security mutually reinforce each other. Countries in East and Southeast Asia offer evidence that poor countries using this strategy can escape from hunger in two decades or less - that is, in the space of a single generation.

Although two decades may seem an eternity to the hungry and those vulnerable to famine, it is roughly the same as the time between the first World Food Summit Conference in 1974 and the second one in 1996. Despite much well-meaning rhetoric at the earlier summit, including Henry Kissinger's pledge that no child would go to bed hungry by 1985, the failure to place food security in a framework of rural-oriented economic growth, in combination with policies to stabilize domestic food economies, meant that those two decades were wasted in many countries. And despite the global community's pledge to reach the Millennium Development Goals by 2015, goals which place an end to hunger at the center of the objectives, there is still no widespread understanding that food security needs to be connected directly to economic growth strategies if these goals are to be achieved.

The focus here is on food security as an objective of national policy. The emphasis is on food security at the "macro" level. At that level, policymakers have an opportunity to create the aggregate conditions in which households at the "micro" level 
can gain access to food on a reliable basis through self-motivated interactions with local markets and home resources. The perspective taken is, thus, primarily an economic one.

At first glance, food security strategies in Asia would seem to have been little influenced by economics. The dominance of rice in the diets of most Asians, coupled to the extreme price instability in the world market for rice, forced all Asian countries to buffer their domestic rice price from the world price. This clear violation of the border price paradigm, and the accompanying restrictions on openness to trade, seems to have escaped many advocates of the East Asian miracle, who saw the region's rapid growth as evidence in support of free trade (World Bank, 1993).

In addition, most Asian governments have paid little attention to formal efforts to define food security as a prelude to government interventions that would be seen as their approach to "food security." The United States position paper for the 1996 World Food Conference, for example, used one version of these standard definitions:

Food security exists when all people at all times have physical and economic access to sufficient food to meet their dietary needs for a productive and healthy life. Food security has three dimensions:

AVAILABILITY of sufficient quantities of food of appropriate quality, supplied through domestic production or imports;

ACCESS by households and individuals to adequate resources to acquire appropriate foods for a nutritious diet; and

UTILIZATION of food through adequate diet, water, sanitation, and health care. (United States Department of Agriculture (USDA), 1996, p. 2)

This definition is obviously an ideal that no country could hope to reach in fact. Instead of debating definitions, the food security strategies of most countries in East and Southeast Asia have had two basic components, neither of which is specifically linked to any of the standard definitions of food security used by international agencies. By contrast, the Asian countries that have been most successful at providing food security to their citizens have based their strategies on two elements of their domestic food system over which they have some degree of policy control: the sectoral composition of income growth, and food prices.

\section{The Strategic Approach to Food Security}

The rate and distribution of economic growth are primarily matters of macroeconomic and trade policy (once asset distributions are given as an initial condition). Although there is now widespread controversy over what role Asian governments played in stimulating growth and channeling its distribution, there is no disagreement that high rates of savings and investment, coupled with high and sustained 
levels of capital productivity, in combination with massive investments in human capital, explain most of the rapid growth that occurred up to 1997 (World Bank, 1993; Timmer, 2004a). Growth that reached the poor-what is now termed "pro-poor growth"-was one component of the food security strategy.

In the second element of the strategy, Asian governments sought to stabilize food prices, in general, and rice prices, in particular. Engel's Law ensures that success in generating rapid economic growth that includes the poor is the long-run solution to food security. In the language of Dreze and Sen (1989), such economic growth provides "growth-mediated security." In the meantime, stabilization of food prices in Asia ensured that short-run fluctuations and shocks did not make the poor even more vulnerable to inadequate food intake than their low incomes required (Timmer, 1991, 1996).

Most economists are highly dubious that such food price stability is financially feasible or economically desirable. It is not a key element of the "support-led security" measures outlined by Dreze and Sen (1989). In a review of food security and the stochastic aspects of poverty, Anderson and Roumasset (1996) essentially dismiss efforts to stabilize food prices using government interventions:

Given the high costs of national price stabilization schemes (Newbery and Stiglitz, 1979, 1981; Behrman, 1984; Williams and Wright, 1991) and their effectiveness in stabilizing prices in rural areas, alternative policies decreasing local price instability need to be considered. The most cost-effective method for increasing price stability probably is to remove destabilizing government distortions. Government efforts to nationalize grain markets and to regulate prices across both space and time have the effect of eliminating the private marketing and storage sector. Rather than replacing private marketing, government efforts should be aimed at enhancing private markets through improving transportation, enforcing standards and measures in grain transactions, and implementing smallscale storage technology (Anderson and Roumasset, 1996, p. 62).

Although this condemnation of national price stabilization schemes might well be appropriate for much of the developing world, it badly misinterprets both the design and implementation of interventions to stabilize rice prices in East and Southeast Asia (Dawe, 2001; Timmer, 1991, 1993, 1996, 2003). For food security in this region, the stabilization of domestic rice prices was in fact feasible in the context of an expanding role for an efficient private marketing sector. The resulting stability was not an impediment, but was actually conducive to economic growth. The stabilization scheme and economic growth worked in tandem to achieve food security as quickly as possible. 


\section{The Micro Dimensions of Food Security}

For the purposes of government policy, food security can be thought of as a continuous spectrum - from the micro perspective of nutritional well-being of individuals all the way to the macro perspective that assures regular supplies of food in national, regional, and local markets. The challenge, and one important objective of food policy, is to create an environment where access to purchasing power, nutritional knowledge, and health care within each individual household assures adequate demand for food in those markets, thus guaranteeing food security at both ends of the micro-macro spectrum. Creating food security at both the micro and macro levels is a complicated task in an open, market-oriented economy, but it is only this kind of economy that can generate rapid growth and reduction of poverty.

Both elements of the Asian strategic approach to food security-rapid economic growth and food price stability_address the "macro" dimensions of food security, not the "micro" dimensions found within the household. Governments can do many things to improve food security at the household and individual level, and most countries in Asia have programs to do so. Rural education accessible to females and the poor, family planning and child-care clinics in rural areas, nutrition education, and extension specialists helping to improve home gardens are just a few of the possibilities (Block et al., 2004). Most of the literature on food security deals with approaches at this level, but problems of definition, measurement, project design, and management vastly complicate strategies that rely on direct household interventions (D. Maxwell, 1996).

These complications, in turn, effectively limit the number of households that can be reached with a micro approach. Without dismissing the potential effectiveness of these approaches to enhancing food security in particular circumstances, it is still important to realize the scale of the problem. Hundreds of millions of people still do not have food security in Asia. Programs delivering food directly to households cannot bring it in a sustainable fashion. Only food security at the macro level can provide the appropriate facilitative environment for households to ensure their own food security.

\section{Growth, Poverty and Stability}

The close historical connection seen in much of East and Southeast Asia between improvements in food security and reduction of poverty has been a result of government efforts to link market-led economic growth to interventions that improve food security at both the household and national levels. This strategic connection is not an accident. A coherently designed macro food policy couples a strategy for food security with a strategy for growth that reaches the poor. Establishing this link to food security from the macro side allows a country to capture growth opportunities, some quite subtle, that are missed otherwise. Such a macro food policy has three components which, in turn, reinforce the country's food security: rapid growth in the macro economy, poverty reduction through rural economic growth, and stability of the food system. Agriculture 
and a dynamic rural economy are the keys to integrating all three components (see Figure $1)$.

This "macro" perspective on the food economy helps integrate a country's food security at the household level with national food markets. In turn, food security at both levels enhances the prospects for rapid economic growth, poverty reduction, and broadbased participation by citizens in higher living standards. The complexity for food policy arises because the achievement of each of the goals pictured in Figure 1 depends on the simultaneous pursuit of the other two strategies, which interact through market and behavioral mechanisms. For example, rapid growth in the macro economy must be designed to reach the poor. Otherwise, poverty reduction is delayed. Likewise, more direct interventions to reach the poor, such as a targeted rice distribution program, cannot be sustained. Similarly, raising poor households above the poverty line does not guarantee their food security if food supplies disappear from markets or prices rise beyond their means.

\section{Figure 1}

\section{A Macro Perspective on the Determinants of Food Security:}

\section{Three "spheres" of activity, held together by agriculture and the rural economy}

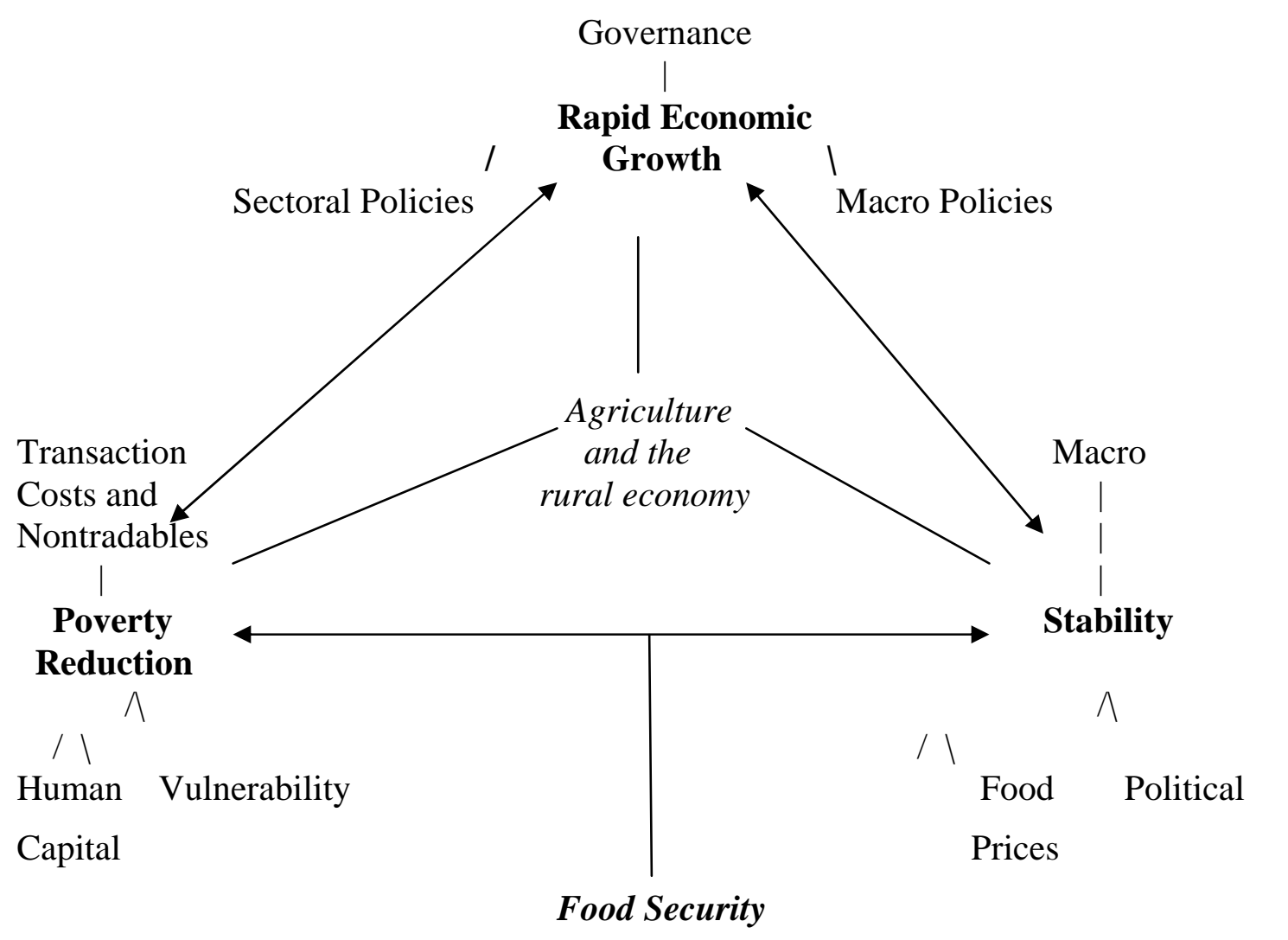

The Primary Role of Economic Growth 
Rapid economic growth has been the main vehicle by which most Asian countries have reduced poverty and enhanced food security (World Bank, 1993). The region has seen substantial variance in growth rates since the 1960s, with China growing extremely rapidly after 1980 and the Philippines growing only modestly since 1961 (see Figure 2).

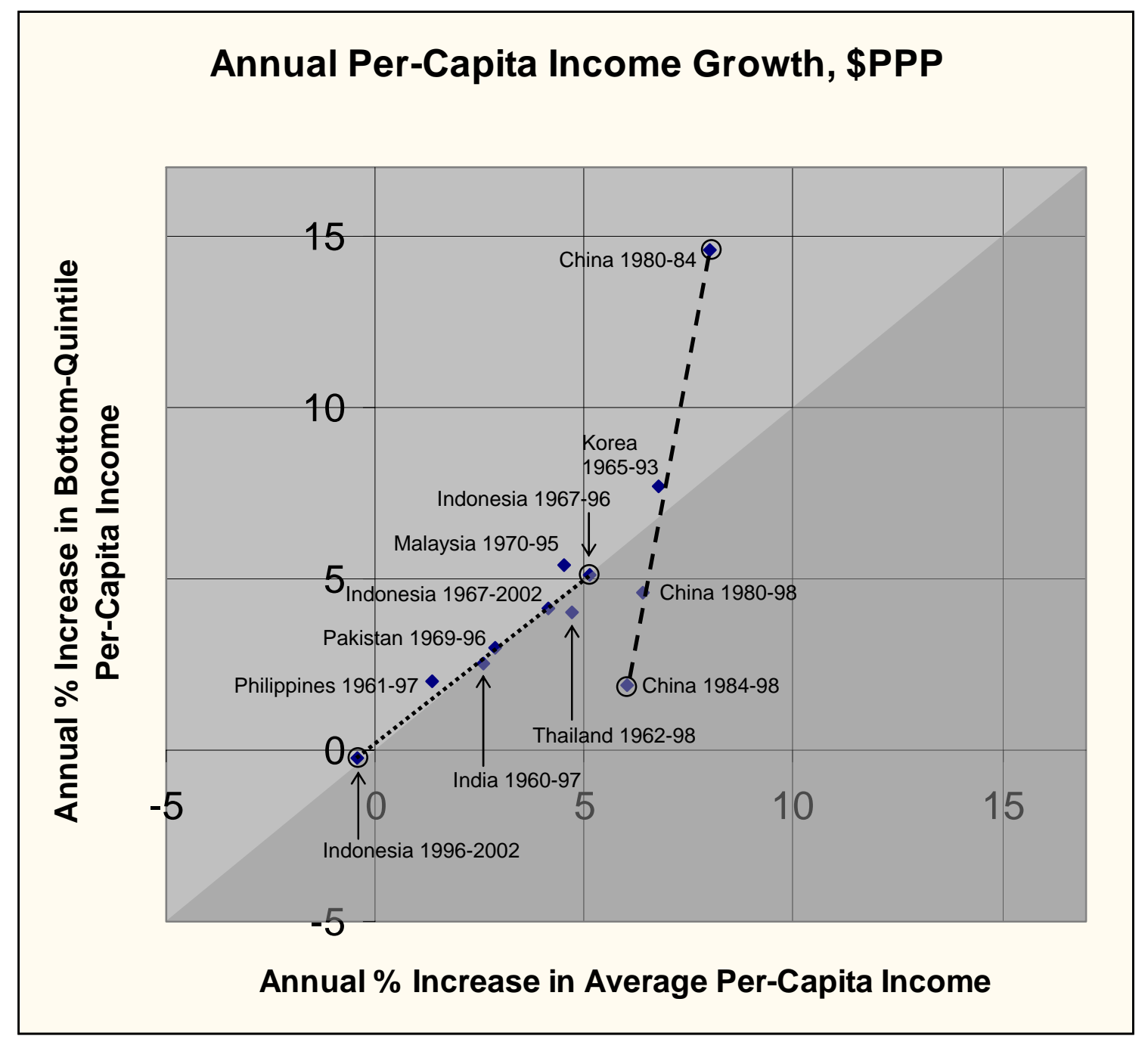

Figure 2. Income Growth for the Bottom Quintile Plotted Against Growth for Average Per Capita Incomes, for Eight Countries in Asia.

SOURCE: Timmer (2004a)

Most countries have averaged growth rates in per capita incomes of between 3 and 4 percent per year, rates that double living standards every two decades or so. When such growth reaches the poor (that is, income distribution does not deteriorate significantly during the growth process), poverty rates can fall from over half the population - the poverty incidence in extremely poor countries - to less than an eighth of the population in just one generation. 


\section{Reaching the Poor}

Such rates of decline in poverty rates were achieved in Indonesia, China and Vietnam since the 1970s, and earlier in Thailand, Malaysia and Northeast Asia. Income distribution tended to be stable, or even improve somewhat, during periods of extremely rapid growth in average incomes per capita (Timmer, 2004a). In addition to the average growth experience for eight Asian countries since the 1960s, Figure 2 also shows that the share of that income earned by the bottom 20 percent of the income distribution (a rough proxy for the poor in most of these countries) tended to be remarkably stable. Most growth experiences lie close to the 45 degree line, where incomes of the poor grow at the same rate as for the rest of the economy.

Despite this long-run stability in income distribution, there is considerable variance in how well the poor connect to economic growth during shorter episodes (Timmer, 1997; 2004a). This variance tends to be explained by initial conditionsespecially land distribution - and by the sector of economic growth. At least in most of Asia, agricultural growth has tended to be much more pro-poor than growth in the modern industrial or service sectors. Finally, rice prices are influential in explaining changes in income distribution. Sharply rising rice prices are bad for the poor.

\section{Stabilizing Food Prices}

All government leaders recognize the impact of rice prices on the poor, and most countries stabilized their rice economy by keeping domestic rice prices more stable than border prices. Economic growth, poverty reduction, and stability are linked to each other through the "virtuous circles" reviewed by Birdsall, Ross and Sabot (1995). Greater stability of the food economy contributes to faster economic growth by reducing signal extraction problems, lengthening the investment horizon, and reducing political instability (Timmer, 1989; Ramey and Ramey, 1995; Dawe, 1996). In the other direction, stability contributes to equity and poverty reduction by reducing the vulnerability of the poor to sudden shocks in food prices or availability. Greater equity also stimulates investment in human capital, especially in rural areas (Williamson, 1993; Birdsall, Ross, and Sabot, 1995), thus speeding up economic growth, at least in the long run.

From 1970 to 1995, Indonesia managed this stabilization process while not deviating far from the long-run trend of prices in the world market (Timmer, 1996). More developed countries in the region, from Japan to Malaysia, kept their rice prices stable at levels that became progressively higher in relation to the price of rice in world markets. Much of this divergence, however, was not due to a conscious policy of raising the real price of rice domestically, but because the world price of rice has declined almost continuously since the mid-1970s. Most of these economies also had appreciating currencies relative to the US dollar, the currency in which world rice prices are quoted.

By implementing a simple policy objective of stabilizing the real domestic price of rice - the operational definition of food security in these societies - most Asian 
countries saw the level of protection of their rice farmers rise sharply from the 1970s to the mid-1990s (Timmer, 1993). Pro-poor economic growth and stable rice prices were the recipe for food security in Asia. The high levels of agricultural protection, and the failure to diversify and modernize their agricultural sectors, were largely unanticipated side-effects from the strategy of growth with stability. Efforts to reduce these high levels of agricultural protection, especially for rice farmers, by directly confronting the political forces defending this “Asian” approach to food security have been repeatedly rebuffed since the 1980s.

\section{Agriculture and the Rural Economy}

For the large countries of Asia, investments since the 1960s to raise the productivity of domestic rice producers brought greater stability to the rice economy at the macro level, mostly because reliance on the world market had been destabilizing in relation to domestic production. Expanded rice production and greater purchasing power in rural areas, stimulated by the profitable rice economy, improved the level and stability of food intake of rural households. The dynamic rural economy helped to reduce poverty quickly by inducing higher real wages. The combination of government investments in rural areas, stable prices at incentive levels, and higher wages helped reduce the substantial degree of urban bias found in most development strategies (Lipton, 1977, 1993). Growth in agricultural productivity has been seen also to stimulate more rapid economic growth in the rest of the economy. ${ }^{2}$

\section{Rural Economic Growth}

The agricultural revolution that swept through East and Southeast Asia since the 1960s dramatically improved the living standards of most people, despite the setbacks from the Asian financial crisis in 1997. By the 1990s, far fewer people were trapped in poverty than in the mid-1960s, food security had been enhanced by surpluses available in an expanded Asian rice market, economies had become highly diversified as the manufacturing sector had outgrown the agricultural sector, and export-oriented companies became competitive in international markets.

The historical and comparative lessons from Asia are clear. They show conclusively that growth of the rural economy has helped the poor more than growth in the urban industrial sector and that such growth has also contributed to more rapid growth in the overall economy (Huppi and Ravallion, 1991; Ravallion and Datt, 1996; Ravallion and Chen, 2004; Sumarto and Suryahadi, 2003; Fan, Thorat and Rao, 2004; Timmer, 1997, 2004b). From the point of view of food security, changes in opportunities

2. An entire body of literature exists that analyzes the role of agriculture in economic growth (Johnston and Mellor, 1961; Eicher and Staatz, 1990; Timmer, 1992, 1995, 2002, 2004b). Specific linkages that have been identified in this literature work through the capital and labor markets, as analyzed by Lewis (1955); through product markets, as specified by Johnston and Mellor (1961); and through a variety of non-market connections that involve market failures and endogenous growth mechanisms (Timmer, 1995, 2002, 2004b). 
for productivity growth in the rural economy influence the stability of the food economy and the possible need for food subsidies targeted directly to the poor, as opposed to incorporating these families into a rapidly growing economy.

These are difficult issues. Designing and coordinating relationships among sectors so that the growth process is rapid, equitable, and sustainable has become a complicated process. The complexity is especially clear in the example of food security, which requires an integration of macroeconomic policies that affect the speed of economic growth, sectoral policies and institutional changes that affect the distribution of that growth and implementation of food distribution and stabilization schemes that guarantee continued access to food by the poor.

\section{Agricultural Productivity}

Improvements in agricultural productivity that have been stimulated by government investment in rural infrastructure, agricultural research and extension, irrigation, and appropriate price incentives have contributed directly to economic growth, poverty reduction, and stability (Timmer, 1992, 1995, 2004b). Throughout Asia, however, rice is no longer the engine of growth in most rural areas. The difficult task has been to conduct research, on a country-specific basis, to discover ways to raise productivity in agriculture per hectare and per worker, to sustain that productivity, and to maintain adequate incentives to ensure continued investment in the sector.

Encompassing all three issues is the need to manage a smooth structural transition by ensuring that the productivity of the rural labor force and its per capita income keep pace with productivity and per capita income in the urban sector. It is no coincidence that all of these issues revolve around productivity. Higher productivity is the only way to achieve and sustain higher living standards in the long run. Income transfers, whether through price policy or direct government subsidies, do not build the economic foundation to support broad-based increases in welfare. Food policy thus must stimulate increases in productivity in the rural economy. Concern for the short-run food intake of the poor, and their nutritional well-being, is also important. But the vehicles that will solve the problem of poverty all involve higher productivity of resource use in the economy (Lipton, 2004).

After the significant gains from the first "Green Revolution" of the 1960s, Asia has had a particularly difficult task in raising agricultural productivity. Since 1990, rice yields on IRRI's (International Rice Research Institute) best experimental plots have stagnated, and there has been only limited evidence of gains in other crops or in the livestock sector. The sources of growth for the higher yields that could form the basis of a second "Green Revolution" have not been identified. Fertilizer and labor have been used very intensively. New biological technologies and improved management of all inputs at the farm level will be needed for the next round of productivity gains.

Both the technologies and the management techniques have had to be fine-tuned to local environments - a process that already has put great stress on central research 
centers to develop locally appropriate varieties and cultivation practices from the basic scientific breakthroughs that have been promised by IRRI and other centers in the CGIAR (Consultative Group on International Agricultural Research) system. In the first instance, this need for technologies to fit local environments has fit nicely with the efforts by many governments to decentralize political decision making and resource management. But the human and scientific resources to implement such an effort have been grossly inadequate, and it will take time to build the local institutions that can carry out these tasks (von Luebke, 2004).

Almost every component of the gains in agricultural productivity since the 1960s has raised concerns about their sustainability. It is possible that soil fertility has been declining. The conversion of fertilizer into useful output has become less efficient. There is less biodiversity. Long-run problems are emerging in managing pests, weeds, and diseases in highly productive ecosystems. There has been increased instability of weather and rainfall patterns - which is possibly a function of global climate change.

Despite these emerging problems of sustainability, the real prices of agricultural commodities in world markets have declined to very low levels in historical terms, and this decline has reduced incentives to fund research that raises agricultural productivity and its sustainability. It has been difficult to justify investments whose payoff has been increased production of exactly these low-value commodities. The real price of rice in world markets has dropped from \$1,000 per metric ton to \$200 per metric ton since 1975 . Many other agricultural commodity prices have followed a similar trend (World Bank, 2004b: Dawe, 2004). Since average farm size has decreased in most countries in Asia because of population growth, finding a technology package and farm-gate price that could raise farm household incomes above the poverty line has become more than four times harder than in the mid-1970s. Agricultural policies in OECD countries have made both tasks even harder (Lipton, 2004).

\section{The Rural Economy and Food Security}

One important outcome of a rural-oriented growth strategy is the achievement of food security. Political pressures to achieve this goal are one of the main driving forces behind the strategy itself. From this political perspective, food security is achieved when economic growth has raised the poor above a meaningful poverty line and when stabilization of the food economy prevents exogenous shocks from threatening their food intake.

In this approach, food security is sustained by the productivity of the poor themselves, but this security continues to depend on public action to maintain a stable macro environment, including the food economy, as an essential complement to that productivity.

Once this process of rapid growth is under way, political tensions inevitably emerge from a structural transformation that takes place too rapidly for resources to move smoothly from the rural to the urban sector (Anderson and Hayami, 1986; Timmer, 1993, 
2002). The entire society is less prone to these tensions if the gap between rural and urban incomes does not widen too much. All successfully growing countries have had to find ways to keep this gap from widening so much that it destabilizes the political economy and jeopardizes continued investment. Managing the transition from "getting agriculture moving” to "manufactured export-led growth" has been a very difficult process throughout Asia, partly because of the very speed of the transition.

\section{Rural-Urban Relationships during the Structural Transformation}

Integrating the three components of the strategy for food security-rapid growth in the macro economy, poverty reduction through rural economic growth, and stability of the food system - is greatly complicated by the changing relationship between the rural and urban economies during the process of industrialization. In all successful economies, incomes earned from farming tend to lag behind those earned in other occupations. Rural labor productivity can increase in two ways: directly in agricultural activities, through the application of new technologies, and indirectly, as workers shift from agriculture to manufacturing or the modern service sector. Both processes are part of the structural transformation, but productivity of urban workers tends to run ahead of rural productivity, causing a pronounced structural lag (Anderson and Hayami, 1986; Timmer, 1988a, 2001, 2002). In most of Asia, from China to Indonesia to India, there has been a growing spread between the wages earned by unskilled agricultural workers and new entrants into labor-intensive manufacturing sectors, such as garments and electronics. At the same time, rice growing has been kept profitable through subsidies, virtually free irrigation water, price support and stabilization programs, and a well-developed rural infrastructure that ensured low marketing margins for rice. Investments in rural education and health helped build human capital, but accumulation of other assets by farmers has been limited.

\section{Managing Food Policy During the Structural Transformation}

The challenge throughout Asia is to modernize agriculture, reduce its heavy dependence on rice through diversification, integrate the entire rural economy more fully into the industrial sector, especially through greater processing activities, and still keep rural incomes high enough to avoid rapid migration of workers to cities. This challenge is not unique to Asia. It is the heart of the tension generated by all successful structural transformations. But the political pressures to resolve the tension can quickly distort policy making and cause massive budget losses, burdens on consumers, and conflicts with trading partners. In particular, efforts to reduce the incomes of rice farmers by bringing domestic prices closer to world prices are seen as worsening the situation, not helping it. A food policy that helps smooth the transition from a poor and rural economy to a rich and urban economy would pay very high dividends, but it must be formulated with a clear understanding of why the structural lag exists and its political link to food security.

Managing policy during the structural transformation thus becomes the 
organizing framework for food policy analysis. The advantage of this perspective is the need to keep long-run objectives and economic forces in focus, at the same time that short-run crises receive urgent attention. For example, even as governments in the region attempt to cope with the problem for rice farmers of low prices in world markets, the structural transformation has reduced the significance of rice to national economies, to consumers, and even to rural incomes. Throughout Asia, most rice-producing families now earn more income from non-rice sources, including non-farm sources, than they do from producing and selling rice. Growing rice is a source of income that is competitive with non-farm wages for only a small share of rural households, and the proportion will continue to fall in the future. If efforts to raise incomes of rice farmers are not consistent with these longer-run forces, the efforts will at best be expensive palliatives that slow down the movement of resources to more highly paid alternatives.

\section{The Political Economy of Agricultural Protection}

It is a sign of great progress that policy makers throughout Asia have come to worry more about keeping rice prices high rather than keeping them low. Historically, in those societies in which poverty has remained untouched or even deepened, the agricultural sector has been seriously undervalued by both the public and private sectors. In addition to an urban bias in most domestic policies, the root cause of this undervaluation was a set of market failures. Commodity prices, by not valuing reduced hunger or progress against poverty, failed to send signals with appropriate incentives to decision makers. These inappropriate signals tend to cause several problems.

First, low values for agricultural commodities in the marketplace are reflected in low political commitments (Bates, 1981). But political commitments to rural growth are needed to generate a more balanced economy (Lipton, 1977; Timmer, 1993). The developing world has already seen a notable reduction in the macroeconomic biases against agriculture, such as overvalued currencies, repression of financial systems, and exploitive terms of trade (Westphal and Robinson, 2002). Further progress might be expected as democracy spreads and empowers the rural population in poor countries (although agricultural policies in most democracies make economists cringe, a point discussed shortly).

The second problem with low valuation of agricultural commodities is that rural labor is also undervalued. This weakens the link between urban and rural labor markets, which is often manifested in the form of seasonal migration and remittances. There is no hope of reducing rural poverty unless real wages for rural workers rise. Rising wages have a demand and a supply dimension, and migration can affect both in ways that support higher living standards in both parts of the economy. Migration of workers from rural to urban areas raises other issues, of course, but those issues depend fundamentally on whether this migration is driven by the push of rural poverty or the pull of urban jobs (Larson and Mundlak, 1997). Whatever the cause, the implications for food security are clear: a greater share of food consumption will be sourced from urban markets. Whether these urban markets are supplied by domestic farmers or international trade is one of the key food security debates under way in most Asian countries. 
So far, the typical response has been for both of these problems to be addressed by trade and subsidy policies that increasingly protect farmers from foreign competition, especially rice farmers. How does urban bias turn so quickly to agricultural protection? The question has fascinated political scientists and economists for some time. Building on Krueger's (1974) and Olsen's (1965) theories of rent-seeking and collective action, Anderson and Hayami (1986) attempted to explain the rapid rise of agricultural protection in Asia in terms of the changing role of agriculture in the structural transformation and the costs of free-riding in political coalitions. A broader effort by Lindert (1991) followed the same approach, which is now formalized as "positive political economy." Actors in both economic and political spheres make rational (personal) choices with respect to policies, using political action, lobbying, and even bribery as mechanisms of influence.

These "rational choice" models of agricultural protection, while illuminating, are not entirely satisfactory. An alternative model that builds on Asian societies' deep desire for food security, manifested as stable rice prices, does a much better job of explaining changes in the nominal degree of protection of rice farmers in Asia (Timmer, 1988b, 1993). It is this deep-seated desire for food security that explains the rapid flip from urban bias to high protection. Newly well-off urban workers no longer need cheap rice in order to survive, but they still must buy all of their rice in local markets. They want to be certain it is available. For societies deeply distrustful of the world market as a source of reliable supplies, it is a very short step to protecting their own rice farmers as the surest vehicle to ensure the availability of rice.

\section{Managing a More Efficient Transition}

Efficient paths to providing food security which are politically feasible have been hard to find. Any such path will involve greater diversification of agricultural production and consumption, including a greater role for international trade, continued commercialization and market orientation, and a balance between the roles of the public and private sectors. At the core will be the welfare of farm households as they struggle with these issues. Mechanisms to enhance asset accumulation, including land consolidation and larger farm enterprises, will be needed for at least some of these households to remain competitive as agricultural producers. Others will exit agriculture. More effective rural credit systems will help this process, but institutional changes in land tenure are also likely to be needed, even if these are mostly in the form of long-term rental arrangements.

\section{Human Capital and Technology}

A key role of the government in developing a dynamic rural economy is the creation of human capital through the provision of education and the improvement of health care. These investments improve the welfare of rural citizens directly through improved life expectancy and a better quality of life. Indirectly, they are keys to 
increasing productivity. Only workers who are knowledgeable and healthy can participate effectively in the development process and choose how best to contribute productively to society, including exiting rural areas altogether by migrating to urban jobs. Education and health care in rural areas are particularly important because the incidence of poverty in rural areas is higher than in urban areas. Furthermore, research has shown that rural education has more beneficial effects on the growth process than does education in urban areas (Timmer, 2002). Rural health care is also important because rural labor is physically demanding.

Technology is an obvious means of increasing productivity in rural areas. Provided the government does not force farmers to use them, new technologies also give farmers and producers a wider range of choices. In rural industry, trade, and services, much of this new technology comes from the private sector, and the primary role of the government is to avoid impeding this process with unnecessary rules and regulations. Even in agriculture, often the best thing the government can do is to remove obstacles to dissemination of private-sector research, as with hybrid corn seed.

In many countries, public-sector agricultural research has made important contributions to productivity growth, with rates of return on investment often much greater than the social opportunity cost of capital. Malaysia's agricultural research system has made tremendous progress in oil palm and rubber, among other crops. In Indonesia, the agricultural research system has created many rice varieties that are planted by farmers throughout the country. Even before the monetary crisis in 1997, rice pesticide sales declined during the 1990s due to the efforts to develop integrated pest management strategies. Yet many challenges remain. Since 1990, rice yields have been virtually stagnant at the major rice research centers. Research institutions need support to make Asian agriculture internationally competitive and allow it to contribute to improved rural, as well as urban, welfare.

\section{Markets and Infrastructure}

In a market economy, macroeconomic stability is essential to long-term poverty reduction in rural areas that are far from the offices of central governments in capital cities, where macro policy is determined. Sustained increases in labor productivity require the accumulation of more physical and human capital per worker. Without a stable real exchange rate and a low rate of inflation, these investments will not be forthcoming, and there will be inadequate job creation in urban and rural areas to absorb a growing labor force with aspirations for a better life. A stable macroeconomic environment is essential for the creation of more job opportunities that mean more choices for rural citizens - farmers, traders, and workers in small- and medium-size enterprises. This increased range of employment choices is the foundation of a dynamic rural economy.

Once macro stability is assured, the provision of infrastructure widens choices for rural dwellers, including the poor. Better roads allow the landless access to a wider range of employment and higher wages through opportunities for migration. Roads offer 
farmers a greater choice of locations in which to market their produce. One study of a group of 45 farmers in a Philippine village well served by infrastructure found that they sold their output to 37 different traders. Such competition makes it far less likely that traders will be able to take advantage of farmers. Roads also give a private firm more freedom to choose its location, allowing the decentralization of industry away from urban areas and providing rural inhabitants with more job choice in rural areas without the need to resort to migration. Rural electrification provides rural citizens access to more information that allows them to participate in the modern economy. In general, physical infrastructure such as roads, ports, and communication networks cause production and marketing systems to become more integrated and function more effectively, providing the base upon which an efficient rural economy can be built. Thailand has had a dynamic rural economy that could compete in a wide range of international markets partly because of its dense road network which connects agricultural production areas with consumption centers and export markets.

Marketing systems need to be predominantly or completely in the hands of the private sector, because only private marketing agents have the necessary detailed knowledge of both producers and consumers. Nevertheless, there is a strong role for government in providing the infrastructure that allows the private sector to perform its services efficiently. While the private sector should not be prevented from building infrastructure, it cannot be relied upon exclusively to perform this task because it typically does not have the ability to capture all the returns from such investments. Thus, it is important for the government to undertake these investments in public goods.

In addition to integrated markets for commodities and inputs, such as fertilizer, efficient and well-functioning rural credit markets are also important if farmers are to be able to reduce the impact of risk and have an effective instrument for asset accumulation. The most important role that government can play in integrating rural credit markets is to ensure macroeconomic stability, which reduces risk and uncertainty and thereby lowers costs in the financial system. Regulations can encourage the formation of rural branch banks, but requiring them is usually counterproductive.

Creation of a dynamic rural economy can occur only in a market-driven environment. Government plays a crucial role in fostering growth, but government cannot be the main engine of productivity growth in rural areas. This lesson has been learned many times over, often at great cost. The rural economies of the former Soviet Union and Eastern Europe were grossly inefficient and did not serve to improve the living standards of their people. Government monopolies on trade in agricultural products inevitably harm farmer interests, as is clearly shown by the experience with commodity boards in Latin America and Africa. In Indonesia and the Philippines, local and national monopolies enjoyed by special interest groups (either inside or outside government) produced the same result-less choice and lower living standards for farmers.

Fortunately, there are many positive results as well. Productivity growth in agriculture surged when China abandoned its control of the rural economy in 1978. As 
Vietnam began to introduce market-oriented reforms in agriculture in 1989, productivity growth accelerated so quickly that Vietnam moved from being a rice importer to the world's second-leading rice exporter.

Recent history has shown conclusively that a network of well-functioning markets is the only mechanism that allows rural citizens to realize their full potential as productive members of society. Governments cannot directly make farmers productive because agriculture is exceedingly complex, heterogeneous, and risky. Farmers operate in a constantly changing physical and economic environment that requires a wealth of micro-level information for efficient decision-making. The amount of information required makes it impossible for government bureaucrats to design sensible micro-level interventions. Farmers must be free to make these choices, both on grounds of economic efficiency and because freedom itself is an important component of human welfare.

\section{The Role of Government}

The new emphasis in development economics on governance as a key factor affecting the rate and distribution of economic growth brings the opportunity to link powerful political forces, such as the deep desire on the part of both urban and rural populations for food security, to the growth process itself. The obvious link is through policy analysis, where the analysis systematically utilizes "neoclassical political economy,” to use Srinivasan's (1985) nomenclature. Understanding the role of markets and the state, and their mutual interaction, will be key.

Within a framework where economic decision makers are free to make choices based on their own knowledge and conditions, the role of government remains critical. In particular, government investments that allow markets to function efficiently are essential to fostering a dynamic rural economy, especially in agriculture. But the government role also spans a wide range of other activities, from macroeconomic policy at the national level to providing immunizations to poor children in remote areas. The key areas where government must provide support to the rural economy are growthoriented economic policies and macroeconomic stability, the generation of new technologies, facilities for the creation of human capital, and the provision of infrastructure to lower transactions costs. All are essential components of a dynamic rural economy. Large gains in agricultural productivity come from such public investments, which create new wealth for all members of society to share. Gains in productivity do not come from changes in price policy (e.g. tariffs), which merely shift income from one group in society to another. From society's point of view, income transfers do not contribute to gains in productivity. The efficient provision of public goods, however, does stimulate such gains. 


\section{An Asian Perspective on Food Security}

Rice is different, and the difference has powerfully influenced economics and politics throughout much of Asia. The difference is manifested in three ways:

--First, rice is the dominant food staple throughout the region, often accounting for more than half of normal food energy intake. Daily access to rice is essential for survival.

--Second, rice is grown predominately by small holders who have been adept at adopting new technologies when market signals were favorable. In many countries, rice farmers are the single largest identifiable voting group.

--Third, international rice markets have been historically thin and unstable, causing all Asian countries to buffer their own farmers and consumers from fluctuating world prices (and thus making the fluctuations worse in an even thinner market). This buffering requires that governments actively control the flow of rice across their borders.

These characteristics of rice-based food systems forge a strong link between politics and economics, a link that policy makers, elected or not, see as a public mandate to deliver food security. Without understanding this link, it is impossible to understand Asia's record of economic growth-driven historically by dynamic rural economiesand the subsequent, seemingly inevitable, rise of agricultural protection. Although some of the forces driving this protection are similar to those in Europe and the United States, the speed, level, and early onset are unique to Asia.

The way forward is to make rice less “different" to consumers, farmers and in world markets, by making it more of an economic commodity and less of a political commodity. As noted above, much progress has actually been made in this direction since the 1980s, but that progress has not been clearly recognized or incorporated into new, politically viable strategies for food security in Asia. Still, the ingredients of such a strategy are clear: greater investment in rural human capital, to improve labor productivity and mobility; more efficient rural financial markets, to facilitate farm consolidation and even rural exit; and coordinated international efforts to open the world rice market to freer trade in order to deepen and stabilize price formation. This is a big agenda, to be sure, but implementing it—even gradually—will ensure a more prosperous and equitable future for Asia's farmers and greater food security for its consumers. 


\section{References}

Anderson, Jock R., and James A. Roumasset. 1996. "Food Insecurity and Stochastic Aspects of Poverty." Asian Journal of Agricultural Economics, Vol. 2, No. I (August), pp. 53-66.

Anderson, Kym, and Yujiro Hayami. 1986. The Political Economy of Agricultural Protection. Sydney: Allen and Unwin.

Bates, Robert. 1981. Markets and States in Tropical Africa. University of California Press: Berkeley.

Behrman, Jere R. 1984. "The Analytics of International Commodity Agreements." In Carl K. Eicher and John M. Staatz, eds. Agricultural Development in the Third World (Baltimore, MD: Johns Hopkins University Press).

Birdsall, Nancy, David Ross, and Richard Sabot. 1995. "Inequality and Growth Reconsidered: Lessons from East Asia." World Bank Economic Review, Vol. 9, No. 3, pp. 477-508.

Block, Steven A., Lynnda Kiess, Patrick Webb, Soewarta Kosen, Regina MoenchPfanner, Martin W. Bloem, and C. Peter Timmer. 2004. "Macro Shocks and Micro Outcomes: Child Nutrition during Indonesia's Crisis.” Economics and Human Biology. Vol. 2, pp. 21-44.

Dawe, David. 1996. "A New Look at the Effects of Export Instability on Investment and Growth." World Development, December, pp. 1905-1914. . 2001. "How Far Down the Path to Free Trade? The Importance of Rice Price Stabilization in Developing Asia.” Food Policy. Vol. 26, pp. 163-175. . 2004. Personal communication, October.

Dreze, Jean, and Amartya Sen. 1989. Hunger and Public Action. Oxford: Clarendon Press.

Eicher, Carl K. and John M. Staatz, eds. 1998. International Agricultural Development. Third edition. Baltimore, MD: Johns Hopkins University Press.

Fan, Shenggen, Sukhadeo Thorat and Neetha Rao. 2004. "Investment, Subsidies, and Pro-Poor Growth in Rural India.” International Food Policy Research Institute, Washington, DC. 
Fogel, Robert W. 1991. "The Conquest of High Mortality and Hunger in Europe and America: Timing and Mechanisms." In Patrice Higonnet, David S. Landes, and Henry Rosovsky, eds., Favorites of Fortune: Technology, Growth, and Economic Development since the Industrial Revolution (Cambridge, MA: Harvard University Press), pp. 35-71.

Huppi, Monica, and Martin Ravallion. 1991. "The Sectoral Structure of Poverty in Indonesia During an Adjustment Period: Evidence for Indonesia in the Mid1980's." World Development, Vol. 19, No. 12, pp. 1653-78.

Johnston, Bruce F. and John W. Mellor. 1961. "The Role of Agriculture in Economic Development." American Economic Review, Vol. 51, No. 4, pp. 566-93.

Krueger, Anne O. 1974. “The Political Economy of the Rent-Seeking Society.” American Economic Review, Vol. 64, pp. 9-24.

Kuznets, Simon. 1966. Modern Economic Growth. New Haven, CT: Yale University Press.

Lewis, W. Arthur. 1955. The Theory of Economic Growth. London: Allen and Unwin.

Lindert, Peter. 1991. “Agricultural Protection in Historical Perspective,” in C. Peter Timmer, ed., Agriculture and the State. Cornell University Press, Ithaca, NY.

Lipton, Michael. 1977. Why Poor People Stay Poor: Urban Bias in World Development. Cambridge, MA.: Harvard University Press.

. 1993. "Urban Bias: Of Consequences, Classes and Causality." In Ashutosh Varshney, ed., Beyond Urban Bias. London: Frank Cass, pp. 229-58.

. 2004. "Crop Science, Poverty and the Family Farm in a Globalising World." Proceedings of the $4^{\text {th }}$ International Crop Science Congress, New Directions for a Diverse Planet, September 26-October 1, Brisbane, Australia.

Maxwell, Daniel G. 1996. "Measuring Food Insecurity: The Frequency and Severity of 'Coping Strategies'." Food Policy, Vol. 21, No. 3 (July), pp. 291-304.

Maxwell, Simon. 1996. "Food Security: A Post-Modern Perspective." Food Policy, Vol. 21, No. 2 (May), pp. 155-170.

Newbery, David M. G., and Joseph E. Stiglitz. 1979. "The Theory of Commodity Price Stabilization Rules: Welfare Impacts and Supply Responses." Economic Journal, Vol. 89, pp. 799-817. 
1981. The Theory of Commodity Price Stabilization: A Study in the Economics of Risk. New York: Oxford University Press.

Olson, Mancur. 1965. The Logic of Collective Action: Public Goods and the Theory of Groups. Harvard University Press, Cambridge, MA.

Ramey, Garey, and Valerie A. Ramey. 1995. "Cross-Country Evidence on the Link Between Volatility and Growth." American Economic Review, Vol. 85, No. 5 (December), pp. 1138-51.

Ravallion, Martin. 1987. Markets and Famines. Oxford: Clarendon Press. . 1997. "Famines and Economics." Journal of Economic Literature. Vol. 35, No. 3 (September), pp. 1205-1242.

Ravallion, Martin, and Shaohua.Chen. 2004. “China’s (Uneven) Progress Against Poverty.” Development Research Group, World Bank, Washington, DC., August, Processed

Ravallion, Martin., and G. Datt. 1996. “How Important to India’s Poor Is the Sectoral Composition of Economic Growth?” The World Bank Economic Review. Vol. 10, no. 1, pp. 1-25.

Sen, Amartya. 1981. Poverty and Famines. Oxford: Oxford University Press.

Srinivasan, T.N. 1985. "Neoclassical Political Economy: The State and Economic Development.” Asian Development Review. Vol. 3, pp. 38-58.

Sumarto, Sudarno, and Asep Suryhadi. 2003. “The Indonesian Experience on Trade Reform, Economic Growth and Poverty Reduction,” Presented at the Trade, Growth and Poverty Conference, December 8-9, London. The SMERU Research Institute, Jakarta, processed.

Timmer, C. Peter. 1988a. “The Agricultural Transformation.” In H. Chenery and T.N. Srinivasan, eds., Handbook of Development Economics. Vol. 1. Amsterdam: North-Holland, pp. 275-331.

. 1988b. Review of The Political Economy of Agricultural Protection: East Asia in International Perspective by Kym Anderson and Yujiro Hayami, in AsianPacific Economic Literature (Canberra), vol. 2, no. 2 (September), pp. 66-69. . 1989. "Food Price Policy: The Rationale for Government Intervention.” Food Policy. Vol. 14, no. 1 (February), pp. 17-42. 
. 1991. "Food Price Stabilization: Rationale, Design, and Implementation," in Dwight H. Perkins and Michael Roemer, eds., Reforming Economic Systems. Cambridge: Harvard Institute for International Development, Harvard University. Distributed by Harvard University Press, pp. 219-48 and pp. 456-59.

. 1992. "Agriculture and Economic Development Revisited." In Paul S.

Teng and Fritz W. T. Penning de Vries, special editors, Agricultural Systems, Vol. 38, No. 5 (Amsterdam: Elsevier), pp. 1-35.

. 1993. "Rural Bias in the East and Southeast Asian Rice Economy:

Indonesia in Comparative Perspective," Journal of Development Studies, Vol. 29, No. 4 (July), pp. 149-76.

. 1995. "Getting Agriculture Moving: Do Markets Provide the Right Signals?" Food Policy, Vol. 20, No. 5 (October), pp. 455-72.

. 1996. "Does BULOG Stabilize Rice Prices in Indonesia? Should It Try?" Bulletin of Indonesian Economic Studies, Vol. 32, No. 2, (August), pp. 45-74.

. 1997. “How Well Do the Poor Connect to Economic Growth?” CAER Discussion Paper, HIID, Cambridge, MA.

. 2000. "The Macro Dimensions of Food Security: Economic Growth, Equitable Distribution, and Food Price Stability.” Food Policy. Vol 25, pp 283295.

. 2001. "Food Supplies and Economic Growth in Great Britain, Japan and Indonesia.” Paper presented at the All-U.C. Group in Economic History Conference on Government and Governance in Economic History, University of California, Berkeley, April 27-29, Pages 29.

. 2002. “Agriculture and Economic Growth.” In Bruce Gardner and Gordon Rausser, eds., Handbook of Agricultural Economics, Vol. IIA. Amsterdam: North-Holland. . 1487-1546.

. 2003. "Food Security and Rice Price Policy in Indonesia: The Economics and Politics of the Food Price Dilemma.” In Mew, T. W., Brar, D. S., Peng, S., Dawe, D., and Hardy, B. eds. Rice Science: Innovations and Impact for Livelihood. Proceedings of the International Rice Research Conference, 16-19 September, 2002, Beijing, China. International Rice Research Institute, Chinese Academy of Engineering, and Chinese Academy of Agricultural Sciences, pp. 777-788.

. 2004a. "The Road to Pro-Poor Growth: Indonesia's Experience in Regional Perspective.” Bulletin of Indonesian Economic Studies, Vol. 40, no. 2 (August), pp. 177-207. 
. 2004b. “Agriculture and Pro-Poor Growth.” Draft manuscript for World Bank project on "Operationalizing Pro-Poor Growth. PREM: Washington, DC. Processed.

, Walter P. Falcon, and Scott R. Pearson. 1983. Food Policy Analysis. Baltimore, MD: Johns Hopkins University Press for the World Bank.

United States Department of Agriculture (USDA). 1996. "The U.S. Contribution to World Food Security." The U.S. Position Paper Prepared for the World Food Summit. Washington, D.C.: United States Department of Agriculture; July 3.

von Luebke, Christian. 2004. "Decentralization and the Grabbing Hand in Indonesia," Ph.D. Thesis proposal, Asia-Pacific School of Economics and Management, Australian National University, Canberra.

Williams, Jeffrey C., and Brian D. Wright. 1991. Storage and Commodity Markets. Cambridge: Cambridge University Press.

Williamson, Jeffrey G. 1993. "Human Capital Deepening, Inequality, and Demographic Events along the Asia-Pacific Rim." In Naohiro Ogawa, Gavin W. Jones, and Jeffrey G. Williamson, eds., Human Resources in Development along the AsiaPacific Rim (Singapore: Oxford University Press), pp. 129-58.

. 1993. The East Asian Miracle: Economic Growth and Public Policy. London: Oxford University Press for the World Bank. 